\title{
KITAP TAHLILI
}

\section{Mübeccel B. KIRAY, «Örgütleșmeyen Kent»,}

\begin{abstract}
İzmir'de İș Hayatının ve Yerleșme Düzeni, Sosyal Bilimler Derneği Yayınları A-I, Ankara 1972.
\end{abstract}

Prof. Dr. Nermin ABADAN-UNAT

Türkiye'nin henüz çok genç sayılan ampirik sosyal bilim araştırmalar alanına bir seri çok ilginç araştırma sonuç ve yorumları sunan halkalı yapıt, kuşkusuz kısaca «İzmir projesi» olarak nitelendirilen kapsamlı bir alan araștırmasıdır. 1967-1968 yılında Ford Vafkınm Türk Sosyal Bilimler Derneğine cömert bağıșlarda bulunmak suretile başlatmış bulunduğu ve proje o sırada SBF'de gö. revli bulunan Prof. Dr. Şerif Mardin'in başkanlığında çeșitli üniversite ve disiplinlere bağlı bulunan araștırmaları bir araya getirmiști. Amaç, bu proje yardımı ile İzmir șehri ve șehrin bugünkui durumunu olduğu kadar tarihî gelişmesini, ilgili sosyal ve ekonomik endikatörler gözönünde tutularak bu kentin fizikî ve coğrafî çevresini insanlararası ilişkileri çeşitli yönleri ile ele almak, sosyal değișme ve gelișme ile birlikte kurumlardaki gelişmeyi ve örgütleşmeyi incelemekti. İmir araștırmalarının bir kısmını anket ve örneklem tekniği bakımından bağlantılı olmakla beraber, bir kısmı da bağımsızdır. Amprik araștırmaların önemli bir kısmı șehrin çekirdeğinde yapılan bir örnekleme dayanmaktadır. Seçim lis. telerinden 8 bin kișilik bir grup, rastlantılı olarak seçilmiş, ilk bilgileri verecek anket onlara uygulanmış, belirli konlara yönelmiş daha ayrıntılı anketler için bu ana örnekten 2 bin ve bin kişilik alt örnekler seçilmiştir.

Bu preje çerçevesinde bugünedek yayınlanmış bulunan monografilerden" Mübeccel B. Kuray'in "Örgütleșmeyen Kent, İmir'de 
Iș Hayatının Yaptsı ve Yerleșme Düzeni» bașliklı araştırması üzerinde etraflıca durmak istiyoruz. Türkiye'de șehir sosyolojisinin çeșitli görünümünü daha önceki amprik araștırmalarında ${ }^{2}$ ele alınmış olan Mübeccel B. Kiray, bu araștırmasında hızla büyüyen bir kısım Türk kentlerinde göze çarpan ikili kentsel yapının nedenlerini ortaya çıkarmağa çalıșmıştır. Kıray'a göre Türkiye'nin kentleri 19. yüzyılda sanayi öncesi iş hayatı düzeninin, hızla genişleyen, ileri teknolojili Batı ekonomik düzeni ile karşılaşması amacında kendine özgü özellikler doğurmuştur. Buralarda, yoğun ve karışık bir dis ticaret ve bunun kontrol mekanizmaları ile eski yersel iç yapısi ve kontrol mekanizmaları yan yana yaşayan yeni bir çift yapı oluşturmuștur. Kıray iște bu sorunu iki düzeyde araștırmıștır. Kitabın birinci kısmında sorunun tarihsel bir görünüm içinde ve tasvir edici (descriptif) bir yöntem yardımı ile ele almış, ikinci kısımda ise Kıray, amprik araştırma yöntemleri, özellikle anketler yardımı ile modernleșmenin derecesini saptamağa çalıșmıștır. K1ray'ın haklı olarak belirttiği gibi bugünedek sosyal değșme araștırmalarında teknolojik değișmelerden, değer değișmelerine kadar pek çok yön üzerinde durulmuşsa da özellikle iş hayatının modernleșmesinde örgüitleşme ve örgütün uzmanlaşma ve giriftlilik derecesi üzerinde pek durumamıștır. Kıray ikinci kısımda iște bu soruna öncelik tanımis bulunuyor.

Yapıtın birinci ve ikinci bölümünde çeșitli tarihî kaynaklar ve bir ölçüde kişisel görüşmeler yardımı ile sanayi öncesi İzmir'in yerleşme biçimi ortaya çıkarılmış bulunmaktadır.

Kanımızca konuyu yepyeni bir ele alış biçimi Izmir kentinin içinde bulunduğu Ege bölgesindeki ekonomik yapısının içindeki

Sosyal Bilimler Derneği Yaymlanı A-2, Ankara 1972 Sh. 87.

II - Emre Kongar, Izmir'de Kentsel Aile,

Sosyal Bilimler Derneği Yaymları: A-3 Ankara 1972, Sh. 80 .

III - Ruşen Keles, İzmir Mahalleleri,

(Bir Tipleștirme Örneği)

Sosyal Bilimler Derneği Yayınları : A-4, Ankara 1972, Sh. 40.

IV - Çiğdem Kâğıtçıbașı, Sosyal Değișmenin Psikolojik Boyutları, (İzmir Lise Öğrencileri Üzerinde Bir Inceleme).

Sosyal Bilimler Derneği Yayınları, Ankaira 1972, Sh. 193.

2) Mübeccel Belik Kıray, Ereğli, Ağır Sanayiden Önce Bir Sahil Kasabası, DPT Yaymi, Ankara 1969, Sh. 256. 
yerleștirme biçimi, (Șekil : 2) ile kentin mekânsal yapısının tahlili sırasında iç limandaki denizin doldurulması suretile elde edilen toprakların hangi amaçlara hizmet ettiği yolundaki yorumlarda yatmaktadır. (Şekil : 3 ve 7).

Kiray'ın açılamalarından anliyoruz ki tarmmsal olan ve olmayan ürünlerin nihaî dağıtım, koordinasyon ve tahsis biçimleri önceleri Osmanlılarda bölge merkezi olan Manisa'da yürütülüyordu. Bu devrede Izmir şehrinin ticaret ve zanaat vergileri Istanbul'a iletiliyordu. Bu bölge yapısı $19 \mathrm{cu}$ yüzyıldan sonra yani bir düzene tâbi oldu. Artan bir dis ticaret ve bu cins ticaretle gelen sosyal örgütler ve guruplar, eski sistemi bozmuşlardır.

Bu durum özellikle 19 cu yüzyılda daha büyüik bir açıklı kazandi. Çünkü Avrupa'nın yeni genişleyen endüstri nüfusu Ege bölgesinin çeşitli vadilerinde üretilen tarımsal ürünlerine giderek talip oldu. Bu arada Osmanl devleti idarî denetimini daha sağlama bağlamak amacı ile İmir'i Saruhan sancağından çkarıp, önceleri Aydın'a bağladı, nihayet 1851'de İzmir'i il merkezi olarak ilân etti. Bu arada İmir'de zanaat ürünleri kaybolmakta, tarımsal ürünlerden sağlanan artık ürün ise yeni bir kontrol çevresine geçmekte olduğu görülmektedir. Bu yeni kontrol çevresi ise tarmmsal ürünlerinin ihracatımı hızlandırmak için teknoloji ayak uyduramadığı yerlerde deve kervanlarını örgütlendirmek gibi tedbirlere de başvurmuștur. (Sh. 13-15) Kiray bu kisımda yeni bir teknoloji $=$ tren ile ilkel bir yersel örgüt ve ilişki $=$ deve kervan șirketlerinin nasıl ahenkli bir sembiyoz içinde yaşıyabildiklerini çok ilginç bir biçimde nakletmektedir. Bazen şekilde haberleşme alanında nasıl yeni tipte bir «mültezim»in ortaya çıtı̆̆ı da belirtilmektedir. Bu arada hizlı artan nüfus karşısında merkezî is mıntıkasının genişleme tarzı, özellikle rıhtım ve demiryollan şirketlerinin İzmir'deki en üst idarecilerinin Kemer deresi vadisi içinde daha sonra Buca adını alan bir banliyöde büyük farklar ıçersinde Avrupa'daki malikâne usulü evlere yerleşmeleri, merkez ile Buca arasinda işleyen banliyö treninin hiçbir istasyonda durmaması ve bilet kesmemesi; benzer bir durumun Bornova denilen banliyöde cereyan etmesi, salt yerleşme açısından Avrupa kapitalizminin Türkiye'deki temsilcilerinin kendileri için elde ettikleri ayricalıklı durumun açıkça doğrulayan kentlerde 1861'de önce Fransız-Belçika şirketinin kıyıyı doldurarak «kordon» ve "gümrük» rihtımını inșa etmesi, bu arada «kordon» arsalarından büyük kàrlar sağlaması, daha sonralan diğer yabancı sirketlerin aynı yöntemi benimsemeleri İzmir şehrinin yarı-koloni döneminde nasıl yabancı şirketlerin 
elile geliștirildiğinin bir kez daha ortaya koymaktadır. İzmir'in tarih içindeki ekonomik ve sosyal gelişmesini değișen ekonomik koşulların ışığı altında işlenen birinci kısım aslında tek başına bir inceleme konusu teşkil etmektedir. İlk bakışta ikinci kısımdan kopuk görünmesi yanıltıcıdır, zira șehrin üçyüz yıl içindeki gelişimi bilinmedikce yirminci yüzyılda hâla bürokratik ölçülere göre «az gelişmiş» olarak kalmasmmn nedenleri ancak bu tarihî analiz yardımı ile aydınlanmaktadır.

Yazar kitabın ikinci kısmını oluşturan III + IV cü bölümde kent olarak İzmir'in son elli yıl içersinde ne ölçüde bir farklılaşma ve uzmanlaşmaya uğradığını tesbite çalışmaktadır. Yirminci yüizyılın ikinci yarısında İzmir'in metropoliten bölgesi onyedi ilçeyi, şehỉr olarak da bir kısım kırsal bölgeleri kapsamaktadır. 1965 sayımlarına göre nüfusu 618.324 i bulan İmir sektör olarak şu dağılımı göstermektedir. \% 12 tarım, \% 25 endüstri, \% 63 hizmetler. Kıray önemli sayıda artmış bulunan denetim ve yönetim görevlerin ne ölçüde bürokrasi niteliği bürünmüş olduğu sorununu ortaya atmaktadır, çünkü gerçek bir endüstrileşme süreci ancak belli ölçüde girift ve karmaşık bürokratik yapıtların ortaya çıkması ile müm. kün olmaktadır.

Bu alanda yaptığı tesbitler şu önemli unsurları ortaya çıartmaktadir :

a) Toptancı ticaret ve tarımsal ürüne dayah yoğun dıs ticaret, bugün de hemen hemen 19 cu yüzyılda olduğu gibi kalmıştır

b) Endüstri, imalat ve bankacılık armıștır,

c) Ulașım ve haberleșme alanında yeni yoğunlul: alanları belirmiștir. (Telefon, telgraf gibi).

d) Isportacı ve ayak satıcıların sayıca çok fazla artmasına karşlık, bu grup hiç uzmanlaşıp, örgütleşmemiștir.

e) Küçük imalatçııı temsil eden "esnaf», aslında büyük fabrika üretimi ile rekabet etmek suretiyle kaynakların kullanılmasinda belirli bir tarzda israfa sebeb omaktadır.

f) Ticaret ve sanayi odasına kayıtlı $5.000 \mathrm{i}$ aşkın işyerinden aslında tüccarlarm hiç değilse dörtte birini, imalatçıların ise yarısı yakınını esnaf ve küiçük imalatçı olarak tasnif etmek gerekir.

Kıray'ın ikinci bölümde üzerinde en fazla durduğu modernleşmenin göstergesi olarak örgütleșmenin zayiflı̆̆ı özellikle bu alanda 
göze çarpmaktadır: Ticaret ve sanayi odalarına kayitlı olanlardan $\%$ 50,5 tek bir idareci kullanmaktadir, 25 kişiden fazla idareci bu. lunan işyeri oranı sadece \% 5,1 dir; işyerlerinin \% 401 hiç kalifiye iş̧̧i kullanmamakta; işyerlerinin sadece $\% 13$ ü sanat okulu mezunu istihdam etmekte; üniversite mezunu istihdam etmeyen işyerlerinin oranı ise $\% 72,6 \mathrm{y} 1$ bulmaktadir.

Kıray daha çok tarıma dayalı yeni endüstri hayatının günümüz İzmir'in mekân içinde yerleșmesine nasıl etki yaptığını belirttikten sonra şu belli bașli sonuçlara ulaşmaktadır :

- Izmir 19 cu yüzyılin sonunda her yönden yeni bir aşamaya ulaşmıştır. Şukadar ki tarımsal üründe ürün değiștiği halde teknoloji ve yerleșme biçimi (dağını, izole köyler) değişmediği için akıtımı temin ve devam ettiren örgütler (ticaret sirketleri, sigortalar, bankalar, demiryolu, rihtım şirketleri) ulașım ve haberleșmenin etkinliğini arttırmak için eski teknoloji ve ilișkelerin bir kısmi yeni uyumlar yapmıs ve yeni tampon roller edinmișlerdir. Bu niteliği ile Izmir tek hâkim parazit (primary city) şehir niteliğini temsil ediyordu.

- Cumhuriyet döneminden bu yana Izmir bu paraziter niteliğinden sıyrılmış, bu arada küçük zanaatkâr imalâtçı ile küçük ticaret önemini kaybetmiș, șukadar ki sinırl bir örgütlü endüstrileșme sebebile İzmir bu halile az gelișmiş bir büyük kentin tüm özelliklerini yansitmaktadır.

Kiray'ın araștırması şehirciler olduğu kadar sosyologlar için de çok önemli yeni ögeler getirmiş bulunmaktadır. Kapitalizmin güç kazanması ve aynî ekonominin yerini malî bir ekonomiye birakması ile gelişmiş bürokrasilerin türeyeceğini «ideal tip» adı altında zihinsel bir imge olarak işlemiş olan M. Weber'in teorisi bu örnek olayda belli bir noktadan sonra neden ișlevsel olmadığmı ve değer yargıların rolünün önemsiz ve etkisiz olduğunu ortaya koymaktadır. Zira girift ve yüksek düzeyli bir iș hayatı yaratan tayin edici unsurlar heryerde: teknoloji-üretim-artık ürün miktarıkontrol ilişkisidir. İmir'de ticaretin hâla endüstriye kıyasla ağır basması, ulusal düzeyin çok üstünde birey bașına gelir ve eğitim görmüș nüfusa sahip olmasina rağmen neden «örgütleșemeyen bir kent», baska bir deyimle neden daha fazla sürekli yeni işyerleri yaratmamakta olduğunu ikna edici biçimde ortaya koymaktadır.

Kıray bugüne dek yayınlamıs olduğu tüm yapıtlarında Türkiye'nin sosyo-ekonomik yapısı ile kentleșme sorunları üzerinde durmuş olan bir sosyal bilimcidir. «Ereğli-Bir Karadeniz Sahili Ka- 
sabası» adlı ilk amprik araștırmasında endüstrileșmeden önceki bir kent ve çevresinde otorite ilişkileri ve tarımsal ekonomiden modernleşmeye geçişi sağliyan tampon kurumları ortaya koymuştur. "Yedi yerleşme noktasında turizmle ilgili sosyal yapı analizi» (1969) ${ }^{3}$ adlı analizinde Ege'nin çeşitli turistik kasabalarının yapısından hareketle ne yönde farkl tutum ve değer yargıları geliştirdiklerini ortaya koymuştur. Adana çevresinde seçtiği dört köyde tarımsal ekonomi alanında yapilan modernleşme çabaları sonucunda neden ilgili köy halkı yerine başka sosyal gruplarının daha çok yararlandiklarını kanıtladığı "Gelişmeye engel olan toplumsal tabakalaşma» $(1970)^{4}$ başlıklı ingiliz dilinde yayınladığı amprik araștırma yine köy/kentin yapısal karakterini belirtmeğe yaramaktadır.

Görülüyor ki M.B. Kıray, Türk șehir sosyolojisi alanında köklï bir mevki işgal etmektedir. Değişik görüș açrlarından yürüttügüü amprik araștırmaları onunu sabırh, azimli ve sürekli bir düșünceye sahip olduğunu ortaya koymaktadir. İleriki araștırmalarında toplumsal ve siyasal sosyalizasyon süreci çerçevesinde yerel ve ulusal seçimlerle baskı gruplarının kentlerin yapısına yaptıkları etki ile de meşgul olacağını ümit etmek isteriz.

3) Mübeccel Kıray, Yedi Yerleşme Noktasında Turizmle Iilgili Sosyal Ya. pr Analizi,

Turizm ve Tanıtma Bakanlığı Yayını No. 2, Ankara 1969, Sh. 141.

4) Jan Hinderink +

Mübeccel B. Krray, Social Stratification as an Obstacle to Development,

A Study of Four Turkish Villages.

Praeger Publisher, New York 1970, Sh. 248. 